\title{
PENGEMBANGAN KULINER LOKAL BERDASARKAN PERSEPSI WISATAWAN DI UBUD, BALI
}

\author{
Ni Komang Nariani \\ Email: nk_nariani@yahoo.com \\ SEKOLAH TINGGI PARIWISATA BALI INTERNASIONAL
}

\begin{abstract}
Ubud is one of the famous tourist destinations in Bali apart of Kuta, Nusa Dua, and Sanur. The Ministry of Tourism proposed Ubud as first Gastronomic Destination in Indonesia with standard UNWTO. Aim of this study to design strategy developmnet of Balinese cuisine based on local tourists' perception in Ubud. This study was conducted in 2018 by qualitative descriptive approach, the data were obtained through observation, interview, and questionnaire to local tourists have enjoying local cuisine at restaurant in Ubud. The data analyzed by Importance Performance Analysis (IPA) with theory Cultural Tourism and Perception theory.

The study conclude is showed tourists 'perception of local culinary good with varietes menu, unique, nice presentation, strategic location, and hospitality staff as expectation but price was high no discount for customer, limited promotion and parking area of restaurant not comfortable. The development strategy strategies offered based on tourists' perception are 1) holding street food, 2) increasing promotion, and 3) arranging the physical evidence of restaurant.
\end{abstract}

Keywords: The Development, Local Culinary, Tourists Perception

\section{Abstrak}

Ubud merupakan salah satu tujuan wisata terkenal di Bali selain Kuta, Nusa Dua, dan Sanur. Kementerian Pariwisata mengusulkan Ubud sebagai Destinasi Gastronomi berstandar United Nations World Tourism Organization (UNWTO) yang pertama di Indonesia. Penelitian ini bertujuan untuk merumuskan strategi pengembangan kuliner lokal berdasarkan persepsi wisatawan nusantara di Ubud. Penelitian dilakukan tahun 2018 menggunakan pendekatan deskriptif kualitatif dengan melakukan observasi, wawancara, dan meyebarkan kuesioner kepada wisatawan yang menikmati kuliner lokal pada restoran atau warung di Ubud. Data dari hasil kuesioner dianalisis dengan Importance Performance Analysis (IPA), menggunakan teori Pariwisata Budaya dan teori Persepsi. 
Hasil penelitian menunjukkan bahwa persepsi wisatawan nusantara terhadap kuliner lokal adalah baik memiliki hidangan beragam, unik, disajikan menarik dengan lokasi restoran strategis dan pelayanan ramah dari karyawan. Harga dinilai mahal, tidak memberikan diskon kepada wisatawan, kurang dipromosikan dan tempat parkir yang kurang memadai. Strategi pengembangan kuliner lokal berdasarkan persepsi wisatawan nusantara yaitu: 1) menggelar street food, 2) meningkatkan promosi, 3) meningkatkan lingkungan fisik restoran.

Kata Kunci: Pengembangan, Kuliner Lokal, Persepsi Wisatawan

\section{Pendahuluan}

Bali sebagai destinasi pariwisata yang terkenal memiliki berbagai jenis makanan dari setiap kabupaten. Makanan lokal merupakan salah satu warisan budaya Bali seperti ayam betutu, bebek goreng, babi guling, lawar, dan sate lilit. Pada awalnya makanan tersebut dipersembahkan pada saat upacara keagamaan namun seiring perkembangan pariwisata disajikan di restoran dan warung baik untuk masyarakat maupun wisatawan. Hal ini menunjukkan terdapat hubungan resiprokal antara wisata budaya dengan wisata kuliner seperti yang terjadi di Ubud, Kabupaten Gianyar (Pitanatri \& Putra, 2016). Wisata kuliner ikut meremajakan daya tarik Ubud sebagai proses rejuvenation atau peremajaan yang dinyatakan dalam teori Tourism Area Life Cycle (Butler, 1980). Wisatawan yang berkunjung ke Ubud untuk menonton tari-tarian, melengkapi pengalaman dengan menikmati kuliner lokal. Wisata kuliner berkembang dan berkontribusi pada pembangunan sosial, ekonomi, dan lingkungan (Corigliano, 2002).

Ubud merupakan salah satu tujuan wisata di Bali selain Kuta, Nusa Dua, dan Sanur. Popularitas Ubud semakin meningkat setelah kesuksesan buku Eat Pray Love tahun 2006 dan filmnya dengan lokasi shooting di Ubud, ditayangkan di bioskop-bioskop tahun 2010 (Yanthy, 2016). Para pengusaha memiliki kontribusi signifikan dalam memperkenalkan kuliner lokal. Pemilik Warung Nasi Ayam Kedewatan Ibu Mangku yaitu Sang Ayu 
Mangku, Anak Agung Oka Raka Sinar, Anak Agung Raka Sueni, dan Wayan Puspawati pendiri Paon Bali Cooking Class mendapat julukan "Srikandi" merupakan pengusaha - pengusaha perempuan yang memperkuat eksistensi Ubud sebagai destinasi kuliner Bali. Media massa dan media sosial memiliki pengaruh besar dalam mempopulerkan wisata kuliner di Ubud (Putra, 2014).

Beberapa ulasan wisatawan pada situs TripAdvisor bahwa makanan Bali memiliki rasa khas, cukup pedas, suasana nyaman di tempat makan, dan cooking class menjadi kegiatan favorit. Adapun ulasan negatif menu dinilai mahal dibandingkan dengan daerah lain, kebersihan tempat, makanan, dan pelayanan karyawan restoran yang kurang memuaskan. Minat wisatawan terbentuk berdasarkan persepsi dan ekspektasi yang dibangun melalui citra Ubud sebagai destinasi wisata kuliner. Persepsi wisatawan merupakan isu penting pada setiap destinasi wisata dan salah satu kunci keberhasilan untuk berkembang dan bersaing dengan destinasi yang lain (Govers \& Go, 2003).

Penelitian ini menggunakan dimensi dari bauran pemasaran $7 \mathrm{P}$ Kotler meliputi: product (produk), price (harga), place (tempat), promotion (promosi), people (orang), process (proses), dan physical evidence (lingkungan fisik). Penelitian ini menarik untuk dilakukan karena beberapa hal yaitu: 1) kajian tentang persepsi wisatawan terhadap kuliner lokal Bali khususnya di kawasan Ubud masih minim, 2) wisatawan memiliki peran penting untuk menilai kuliner lokal baik positif maupun negatif, 3) persepsi wisatawan sebagai umpan balik bagi stakeholder dalam melakukan pengembangan kuliner lokal di Ubud.

Rumusan masalah dari penelitian ini berdasarkan uraian latar belakang tersebut adalah:

1. Bagaimana persepsi wisatawan nusantara terhadap kuliner lokal di Ubud, Bali? 
2. Bagaimana strategi pengembangan kuliner lokal berdasarkan persepsi wisatawan nusantara di Ubud, Bali?

Penelitian ini bertujuan untuk merumuskan strategi pengembangan kuliner lokal berdasarkan persepsi wisatawan nusantara di Ubud. Adapun maanfaatnya untuk Lembaga Pendidikan Pariwisata, pengusha kuliner, dan pemerintah.

\section{Tinjauan Pustaka}

Penelitian tentang pariwisata dan usaha kuliner banyak dilakukan oleh para peneliti dan terus berlanjut seiring dengan munculnya berbagai fenomena. Beberapa dari peneliti tersebut antara lain: Reynolds (1993) yang didukung oleh Hendrayana (2011) bahwa kuliner lokal tidak banyak disajikan pada restoran dan hotel-hotel di kawasan Sanur. Menurut Jalis, dkk (2009) persepsi wisatawan Barat terhadap kuliner lokal Malaysia adalah baik, pengusaha harus menyesuaikan produk sesuai harapan wisatawan.

Pengusaha kuliner memiliki kontribusi penting dalam memperkenalkan kuliner Bali kepada wisatawan. Pemilik Warung Nasi Ayam Kedewatan Ibu Mangku yaitu Sang Ayu Mangku, bersama Anak Agung Oka Raka Sinar pemilik Warung Babi Guling Ibu Oka, Anak Agung Raka Sueni perintis Bebek Bengil Restaurant, dan Wayan Puspawati pendiri Paon Bali Cooking Class mendapat julukan "Srikandi Kuliner Bali". Media massa dan media sosial juga memiliki pengaruh besar dalam mempopulerkan wisata kuliner di Ubud (Putra, 2014).

Pengusaha kuliner perempuan memiliki kontribusi mempromosikan kuliner lokal dalam pariwisata di Bali (Yanthy, 2016). Penelitian yang dilakukan oleh Adiprana (2017) tentang Ekspektasi dan Persepsi Wisatawan Terhadap Kuliner Lokal di Ubud bahwa faktor higienitas kurang baik. Kuliner Bali selain disajikan pada restoran dan 
warung juga di restoran kelas atas atau upscale restaurant seperti bebek betutu di Swept Away Ubud dengan harga yang tinggi (Hardini, 2018).

Penelitian ini menggunakan teori Pariwisata Budaya karena memiliki ruang lingkup luas dan mengakibatkan adanya bentuk-bentuk pariwisata alternatif seperti wisata kuliner. Budaya adalah sesuatu yang meliputi pengetahuan, kepercayaan, seni, moral, hukum, norma serta berbagai kebiasaan diperoleh seseorang sebagai bagian dari masyarakat. Teori Persepsi digunakan karena budaya merupakan nilai-nilai yang berubah seiring perkembangan jaman. Menurut Rangkuti (2003) nilai yang diberikan wisatawan merupakan pengkajian secara menyeluruh maanfaat dari suatu produk, berdasarkan persepsi pelanggan.

\section{Metodologi}

Penelitian dirancang menggunakan pendekatan kualitatif, dilaksanakan tahun 2018 dengan 75 orang wisatawan nusantara sebagai responden yang berkunjung pada sembilan restoran atau warung, dan cooking class di Ubud. Nama-nama objek penelitian yaitu: Warung Nasi Ayam Kedewatan Ibu Mangku, Murni's Warung, Warung Babi Guling Ibu

Oka, Cafe Wayan Restaurant, Bebek Bengil Restaurant, Laka Leke Restaurant, Arma Cafe, Paon Bali Cooking Class, dan Ketut's Bali Cooking Class.

Data kualitatif diperoleh dari hasil observasi dan wawancara kepada informan yaitu: Tokoh Puri Ubud, Pakar dan Pemerhati Kuliner Indonesia pada Ubud Food Festival 2018, Penasehat Indonesian Chef Association (ICA) di Kampus STPBI. Pemilik Murni's Warung yaitu Wayan Murni di Murni's House \& Spa, Ketut Sudarta sebagai manajer di Bebek Bengil Restaurant, dan I Ketut Budiasa juga I Wayan Sarma pemilik Ketut's Bali Cooking Class di Banjar Laplapan Desa Petulu Ubud. 
Data kuantitatif berupa hasil kuesioner mengadopsi dari Johar (2013) disebarkan kepada 75 wisatawan nusantara yang mengunjungi dan menikmati kuliner lokal pad objek penelitian. Data dianalisis menggunakan Importance Performance Analysis (IPA) yang diperkenalkan oleh Martilla \& James (1977) terdiri dari empat kuadran: I Prioritas Utama, II Pertahankan, III Prioritas Rendah, dan IV Berlebihan.

\section{Persepsi Wisatawan Nusantara}

\subsection{Profil Lokasi Penelitian}

Ubud sebagai destinasi wisata kuliner memiliki banyak tempat makan berupa restoran, warung, dan cooking class yang menyajikan kuliner lokal juga non-lokal untuk memenuhi kebutuhan wisatawan. Warung Nasi Ayam Kedewatan Ibu Mangku berdiri tahun 1960-an dengan lokasi strategis di Jalan Raya Kedewatan. Pada awalnya sebagai tempat makan para guide atau pengemudi mobil travel yang melewati daerah tersebut. Namun seiring waktu banyak dikunjungi wisatawan baik nusantara maupun mancanegara. Menu nasi campur yang khas terdiri dari: ayam betutu, sate lilit, telur, sayur urab, kacang goreng, dan sambal disajikan halal karena berbahan baku dari ayam dengan harga terjangkau. Warung ini telah membuka cabang usaha di Renon-Denpasar dan Seminyak-Badung.

Murni's Warung berlokasi di tepi sungai Wos di Jalan Raya Campuhan. Menurut Wayan Murni saat didirikan pada tahun 1974, tampilan warung sangat sederhana diawali dengan menjual kain-kain dan sandwich kemudian ditambah menu nasi campur. Namun saat ini telah memiliki fasilitas berupa dining room, bar, lounge, dan gallery tempat menyimpan berbagai benda antik koleksi Ibu Murni. Hidangan yang disajikan selain kuliner lokal juga menu ala Barat yang diminati wisatawan. 
Warung Babi Guling Ibu Oka, didirikan tahun 1980-an berlokasi di sebelah Banjar Pekraman Ubud. Menu satu-satunya yang dijual adalah babi guling, banyak dikunjungi oleh wisatawan nusantara dan wisatawan mancanegara. Warung tersebut semakin terkenal setelah diliput oleh Anthony Bourdain, selebriti dan pengamat kuliner yang menyatakan bahwa Babi Guling Ibu Oka merupakan salah satu terbaik yang pernah dirasakan. Warung Babi Guling Ibu Oka, memiliki tiga tempat usaha di kawasan Ubud.

Cafe Wayan Restaurant, didirikan oleh Sang Ayu Wayan tahun 1960-an berlokasi di Jalan Monkey Forest Ubud. Pengelola Cafe Wayan adalah Wayan Metri dan Wayan Artika yang menyajikan nasi campur sebagai menu handalan dan memiliki fasilitas cooking class. Lokasi yang strategis dengan kebun asri menambah suasana nyaman kepada wisatawan. Cafe Wayan memiliki cabang di Lombok, Nusa Tengggara Barat.

Bebek Bengil Restaurant dirintis oleh Anak Agung Raka Sueni pada tahun 1990 berlokasi di Jalan Hanoman, memiliki cabang di The Bay kawasan ITDC-Nusa Dua dan di Jakarta. Hidangan utamanya menyajikan bebek goreng atau crispy duck. Menurut Ketut Sudarta, sebagai manajer restoran untuk bahan baku bebek selain dipenuhi dari Bali juga dari Jawa. Kedatangan selebriti dunia seperti Mick Jagger dan Jerry Hall membuat Bebek Bengil Restaurant semakin dikenal luas.

Laka Leke Restaurant, nama tersebut diambil dari istilah Bali lekeleke yang artinya terpencil, karena memang lokasinya di Dusun Nyuh Kuning. Ketut Setia sebagai pemilik, merintis dan mengembangkan usahanya sejak tahun 1997 saat pariwisata di Ubud belum berkembang pesat seperti saat ini. Menu handalan kuliner Bali adalah bebek crispy, diolah mengunakan bebek lokal yang diberi pakan organik untuk menjaga kualitas rasa. Pada malam hari sambil menikmati makanan, wisatawan dapat menonton tari-tarian sehingga memberi pengalaman yang unik. Laka 
Leke Restaurant juga memiliki fasilitas cooking class. Arma Cafe didirikan pada tahun 1996 oleh Anak Agung Rai Suartini di Pengosekan, mengusung konsep restoran terbuka berada di lingkungan Museum Arma. Menu yang disaajikan selain kuliner lokal juga Western dan makanan Thailand. Wisatawan dapat menikmati hidangan dengan santai dan lokasi yang strategis.

Paon Bali Cooking Class merupakan pelopor di Banjar Laplapan, Desa Petulu-Ubud dirintis oleh Wayan Puspawati bersama suaminya Wayan Subawa. Paon yang artinya dapur menunjukkan identitas sebagai tempat memasak untuk diperkenalkan kepada wisatawan. Kegiatan cooking class dilaksanakan pada pagi dan sore hari. Para peserta diperkenalkan dengan berbagai macam bumbu, diberi penjelasan, dan belajar cara mengolah masakan termasuk menumbuk bumbu.

Ketut's Bali Cooking Class dulu dikenal dengan nama Payuk Bali yang artinya periuk, dikelola oleh I Ketut Budiasa dan I Wayan Sarma di Banjar Laplapan. Peserta diperkenalkan cara membuat minyak kelapa yang menjadi bahan saat mengolah masakan. Jenis menu yang dimasak tidak terbatas pada makanan lokal tetapi juga hidangan nusantara seperti nasi goreng dan mie goreng untuk membantu peserta yang belum terbiasa dengan makanan Bali.

\subsection{Karakteristik Kuliner Lokal}

Manusia tidak dapat lepas dari makanan dan minuman, yang telah berkembang menjadi bagian dari gaya hidup. Pola makan dan jenis makanan menggambarkan perilaku seperti: kesehatan, lingkungan, dan sistem sosial masyarakat (Klub Gastronomi Indonesia, 2014). Menurut I Made Kornelius, sebagai Penasehat Indonesian Chef Association (ICA) bahwa kuliner lokal memiliki karakter yang unik pada umumnya pedas karena berbagai bumbu lengkap "base genep". Kuliner Bali memadukan 
enam rasa yang disebut dengan sad rasa yaitu: pakeh/asin simbol pengalaman atau sukses yang telah dicapai, lalah/pedas simbol kemarahan, masem/asem sebagai kegagalan, manis berarti kebahagiaan, pahit simbol atas rasa sakit atau kekecewaan, dan rasa sepek simbol kedinamisan.

\subsection{Ubud Sebagai Destinasi Gastronomi}

Kuliner telah menjadi bagian dari gaya hidup dan tidak dapat dipisahkan dari kegiatan pariwisata. Jumlah restoran dan warung makan yang semakin bertambah di Ubud, menjadikan wisata kuliner sebagai salah satu tujuan wisatawan. Kuliner lokal merupakan bagian penting dari gastronomi karena tidak hanya memberi pengalaman namun menghubungkan segala sesuatu yang menyertai seperti: budaya, sejarah, seni, dan kesehatan.

Kementerian Pariwisata mengusulkan Kabupaten Gianyar khususnya Ubud sebagai Destinasi Gastronomi berstandar UNWTO yang pertama di Indonesia pada tahun 2018. Adapun lima standar sebagai syarat yaitu: kuliner menjadi lifestyle, memiliki nilai sejarah dan budaya, produk lokal, dapat diceritakan/story telling, dan memenuhi nutrisi. Ubud dipilih dengan beberapa pertimbangan seperti yang disampaikan oleh Vita Datau Messakh, Ketua Tim Percepatan Pengembangan Wisata Kuliner dan Belanja. Ubud dinilai memiliki kelengkapan perpaduan kuliner tradisional dan kuliner internasional, kesiapan suplai produk, nilai kelokalan, dan kemampuan para chef.

\subsection{Deskripsi Karakteristik Responden}

Wisatawan nusantara 75 orang terdiri dari 36 laki-laki dan 39 perempuan, didominasi oleh generasi milenial berasal dari Pulau Jawa 50 orang yang 25 responden dri daerah lain. Lulusan perguruan tinggi 64 dan 11 responden berstatus pelajar. Pekerjaan sebagai tenaga pendidik 23, 
pengusaha 13 , pensiunan 14 , pelajar 11, dan profesi lain 14 responden. Kunjungan pertama kali dilakukan oleh 28 dan 47 responden melakukan kunjungan berulang. Tujuan utama untuk makan siang 47 dan makan malam 28 responden. Kunjungan bersama rombongan 61 dan 14 responden berkunjung ke restoran sendirian. Hal yang paling berkesan adalah lokasi, menu, dan pengalaman budaya.

\subsection{Persepsi Wisatawan Nusantara}

Menurut Rangkuti (2003) bahwa nilai yang diberikan wisatawan merupakan pengkajian secara menyeluruh maanfaat dari suatu produk didasarkan pada persepsi pelanggan. Persepsi wisatawan nusantara terhadap kuliner lokal secara umum adalah baik. Dimensi produk dinilai memiliki beragam menu, unik, disajikan menarik, bahan dan proses bersih. Hal tersebut berbeda dengan temuan Adiprana (2017) bahwa faktor kebersihan dan higienitas perlu mendapat perhatian.

Wisatawan nusantara menilai harga kuliner lokal mahal bila dibandingkan dengan daerah lain. Persepsi tersebut seperti beberapa komentar di TripAdvisor yang menyatakan makanan seperti babi guling di Ubud mahal, kurang sesuai dengan porsi yang disajikan. Lokasi restoran atau warung di Ubud strategis dengan suasana nyaman. Dimensi promosi mendapat nilai rendah bahwa kuliner lokal belum di promosikan dengan menarik baik di media cetak dan elektronik. Beberapa restoran dan warung yang terkenal hanya melakukan promosi word of mouth atau dari mulut ke mulut.

Karyawan restoran pada dimensi orang telah memberikan pelayanan yang baik, cepat tanggap kepada wisatawan. Prosedur dan kejelasan waktu pelayanan pada dimensi proses mendapat persepsi baik. Restoran dan warung memiliki desain dan tata ruang menarik, bersih dan 
rapi namun ketersediaan tempat parkir belum sesuai harapan wisatawan pada lingkungan fisik.

\section{Strategi Pengembangan Kuliner Lokal}

Pada Gambar 5.1 hasil Importance Performance Analysis (IPA) bahwa indikator dimensi harga berada pada kuadran I prioritas utama. Indikator dimensi produk, tempat, dan orang pada kuadran II dipertahankan sedangkan indikator dari promosi, proses, dan lingkungan fisik berada pada kuadran III dengan katagori prioritas rendah.

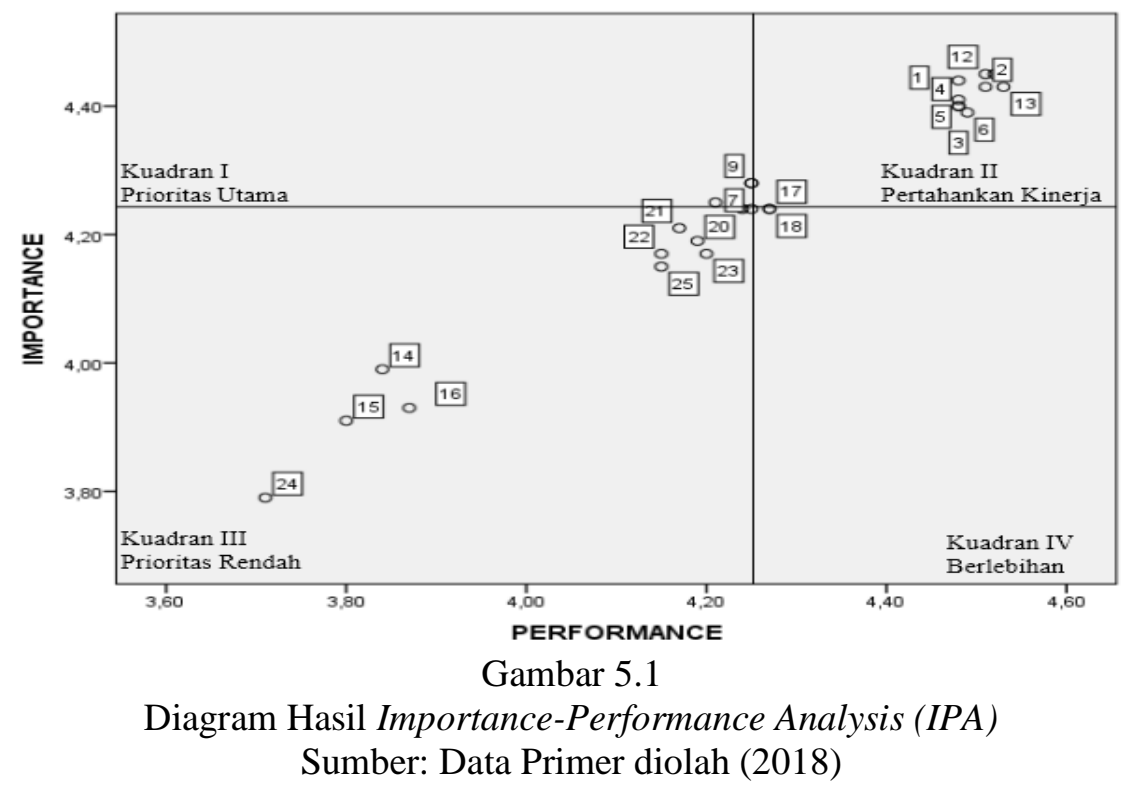

Kuliner lokal merupakan salah satu faktor yang mempengaruhi keputusan wisatawan untuk melakukan wisata kuliner di Ubud. Menikmati kuliner lokal yang berkualitas dapat memberi pengalaman bagi wisatawan. Teori Pariwisata Budaya bahwa wisatawan pada Abad ke-21 cenderung tertarik dengan produk kuliner lokal dengan tujuan dapat merasakan sejarah dan sosial budayanya. Wisata kuliner dinilai sebagai praktek kebudayaan dan kuliner lokal merupakan warisan budaya. Berdasarkan 
persepsi wisatawan nusantara, maka strategi pengembangan kuliner lokal di Ubud sebagai berikut:

\subsection{Menggelar Street Food}

Pemerintah memprakarsai menyelenggarakan street food dengan melibatkan pengusaha dan masyarakat, dapat memberikan pilihan kepada wisatawan. Khan (2017) menyatakan bahwa kuliner Thailand menjadi salah satu daya tarik bagi wisatawan mancanegara baik tua maupun muda, khususnya street food yang memiliki keunikan dibandingkan restoran formal. Pada umumnya wisatawan usia muda memiliki sistem imunitas lebih baik mencerna street food. Standar kebersihan dalam penyajian dan kelayakan bahan makanan harus tetap diperhatikan (Yeung \& Morris, 2001).

\subsection{Meningkatkan Promosi}

Ubud yang telah diusulkan sebagai Destinasi Gastronomi, diharapkan lebih aktif dalam memperkenalkan kuliner lokal Bali. Dalam wawancara dengan Tokoh Puri Ubud, Tjokorda Oka Artha Ardana Sukawati menyampaikan bahwa kuliner Bali memiliki resep yang berbeda antara satu daerah dengan yang lain. Hal tersebut menjadi kendala dalam mempromosikan secara satu kesatuan wilayah sehingga perlu adanya resep yang standar dan tertulis.

Pemerintah bekerjasama dengan pengusaha kuliner bekerjasama dalam melakukan promosi, meningkatkan jumlah event atau festival kuliner lokal dan memaanfaatkan media sosial. Pengusaha terus berupaya untuk membuka cabang usaha baik di Bali maupun diluar Bali seperti yang telah dilakukan oleh beberapa pengusaha kuliner. Penelitian Rumadana (2013) menemukan bahwa pengembangan kuliner lokal Bali keadaannya masih jalan di tempat. Pertumbuhan restoran semakin besar namun produk 
yang dijual bukan makanan tradisional Bali, melainkan makanan Korea, India, China, dan Italy.

\subsection{Meningkatkan Lingkungan Fisik Restoran}

Wisatawan yang berkunjung ke restoran atau warung tidak hanya untuk menikmati kuliner lokal. Kenyamanan saat makan menjadi faktor penting dalam menentukan pilihan tempat. Lingkungan fisik merupakan suatu upaya manusia untuk mendesain lingkungan dengan tujuan menciptakan emosi yang berpengaruh terhadap niat berperilaku konsumen (Kurniawan et al, 2017). Menurut Ryu \& Han (2010), DINESCAPE merupakan segala hal yang berasal dari karya manusia serta bentuk fisik dibagian dalam restoran, tidak termasuk area luar terdiri dari enam konsep yaitu: facility aesthetic, ambience, lighting, layout, table setting, dan service staff.

\section{Simpulan}

Persepsi wisatawan nusantara terhadap kuliner lokal di Ubud berdasarkan dimensi 7P, secara umum adalah baik. Menu beragam, unik, disajikan menarik dengan lokasi restoran strategis dan suasana nyaman. Harga dinilai mahal, belum dipromosikan dengan baik bahkan beberapa restoran yang terkenal karena word of mouth model promosi konvensional. Dimensi proses mendapat persepsi baik sesuai harapan wisatawan. Restoran memiliki desain dan tata ruang menarik, bersih dan rapi namun masih sulit ditemukan area parkir yang mudah di akses.

Strategi pengembangan kuliner lokal di Ubud, berdasarkan persepsi wisatawan nusantara adalah: 1) menggelar street food dengan harga terjangkau, 2) meningkatkan promosi dengan menetapkan resep yang standar dan tertulis, menambah jumlah event atau festival kuliner, 3) meningkatkan lingkungan fisik restoran dengan konsep DINESCAPE. 


\section{Daftar Pustaka}

Adiprana, I.P.G. 2017. Ekspektasi dan Persepsi Wisatawan Terhadap Kuliner Lokal di Ubud. Denpasar: Tesis Pascasarjana Universitas Udayana.

Ardika, I.W. 2004. "Pariwisata Bali: Membngun Pariwisata Budaya dan Mengendlikan Budaya Pariwisata”. Dalam Bali Menuju Jagadhita: Aneka Perspektif. Denpasar: Pustaka Bali Post

Butler, R.W., 1980. The concept of a tourist area cycles of evolution: implications for management of resources. The Canadian Geographer/Le Geographe canadien, 24(1), pp.5-12

Corigliano, A. 2002. The route to quality: Italian gastronomy networks in operations. Tourism and Gastronomy (pp.166-185). London: Routledge

Gover, R. Dan Go, F. 2003. Deconstruction destination image in the transformation age. Information Technology and Tourism, 6(1), pp.13-29

Hardini, W. 2018. Memorable Experience Wisatawan pada Restoran Upscale di Bali (disertasi). Denpasar: Universitas Udayana

Hendrayana, M. 2011. Strategi Pengembangan Wisata Kuliner Bali Pada Kawasan Hotel Di Sanur (thesis). Denpasar: Universitas Udayana

Jalis, M.H., Zahari, M.S.M., Izzat, M. and Othman, Z. 2009. Western tourists' perception of Malaysian gastronomic products. Asian Social Science, 5(1), pp. 25

Kivela, J., \& Crotts, J. C. 2006. Tourism and gastronomy: Gastronomy's influence on how tourists experience a destination. Journal of Hospitality \& Tourism Research, 30(3), pp.354-377.

Kotler, P. 2014. Manajemen Pemasaran. Jakarta: PT. Indeks

Kurniawan, D.A.A., Karenila, K. and Jokom, R., 2017. Analisa Pengaruh Lingkungan Fisik Terhadap Niat Berperilaku Melalui Emosi Konsumen Di Domicile Kitchen \& Lounge Surabaya. Jurnal Hospitality dan Manajemen Jasa, 5(1), pp.111-123.

Martilla, J.A. and James, J.C. 1977. Importance-Performance Analysis. Journal of Marketing, No. 41, 77-79

Putra, I.N.D. 2014. Empat Srikandi Kuliner Bali: Peran Perempuan Dalam Pembangunan Pariwisata Berkelanjutan. Jurnal Master Pariwisata (Journal Master in Tourism Studies), 1(1) pp.65-94

Reynolds, P.C. 1993. Food and tourism: towards an understanding of sustainable culture. Journal of Sustainable Tourism, 1(1), pp.48-54

Ryu, K. and Han, H. 2010. Influence of Physical Environment on Disconfirmation, Customer Satisfaction, and Customer Loyalty for First-time and Repeat Customers in Upscale Restaurants. International CHRIE ConferenceRefereed Track Vol. 13 pp 1-8.

Suharman. 2005. Psikologi Kognitif, Surabaya: Srikandi.

Sujatha, D.K. 2013. "Adaptasi Seni Kuliner Bali Menjadi Boga Wisata". Jurnal Gastronomi Indonesia, (2)1, pp. 52-64

Yanthy, P.S. 2016. Kontribusi Perempuan dalam Mengangkat Kuliner Lokal untuk Mendukung Pariwisata Bali. Denpasar: Disertasi Pascasarjana Universitas Udayana 